\title{
An Evaluation of the Implementation Synergy between NCE-Integrated Science and the 9-Year Basic Science Curricula in Nigeria
}

\author{
Rachel O. Atomatofa ${ }^{1,},{ }^{*}$, Andrew E. Abvenagha ${ }^{2}$, Ewesor E.Stella ${ }^{3}$ \& Abugor C. Okpako ${ }^{4}$ \\ ${ }^{1}$ Integrated Science Department(science methodology option), Delta State College of Physical Education, Mosogar, \\ Nigeria \\ ${ }^{2}$ Integrated Science Department(physics option), Delta State College of Physical Education, Mosogar, Nigeria \\ ${ }^{3}$ Integrated Science Department(biology option), Delta State College of Physical Education, Mosogar, Nigeria \\ ${ }^{4}$ Integrated Science Department(chemistry option), Delta State College of Physical Education, Mosogar, Nigeria \\ *Correspondence: C/o Delta State College of Physical Education Mosogar, P. O. Box 4088 Sapele, Delta. State \\ Nigeria. Tel: 234-706-235-1895. E-mail: atomatofa.ro@gmail.com
}

Received: June 15, 2018 Accepted: July 18, 2018 Online Published: August 6, 2018

doi:10.5430/jct.v7n2p55 URL: https://doi.org/10.5430/jct.v7n2p55

\begin{abstract}
The Curriculum of the Nigeria Certificate in Education (NCE) has implications for the Curriculum of the 9-year Basic Education (BEC) programme in Nigeria. Hence the National Commission for Colleges of Education (NCCE) came up with a vision of producing well motivated teachers with high professional integrity and competence. Both the in-service and pre-service teachers need to be conversant with the content of the 9- year Basic Education Curriculum (BEC). Are there implementation synergies in the topics, laboratory exercises and nature of assessment in the NCE integrated Science and the 9-year basic science curricula as perceived by the in-service and pre-service teachers who are recipients of the NCE-integrated science curriculum and who also implement the 9-year basic science curriculum? 4 research questions and 4 research hypotheses guided this study. A sample of 180 pre-service and in-service basic science teachers who are recipients of the new 2012 NCCE Curriculum in Integrated-science from the South - South Geo-political zones in Nigeria were used. A 4-point Likert scale '24-item questionnaire' called the Curriculum Implementation Synergy Questionnaire was used to obtain data. A cronbach alpha reliability co-efficient of 0.75 was obtained. Results showed that a larger proportion of both pre-service and in-service teachers agreed that there was high level of synergy in both curricula. It is recommended that the few topics and laboratory exercises not found in both curricula should be added and the present basic science teachers who are not recipient of the present curriculum should be trained in line with the present curriculum.
\end{abstract}

Keywords: teachers, curriculum, synergy, basic science, integrated-science

\section{Introduction}

The National Commission for Colleges of Education (NCCE) in Nigeria is guided by the vision of producing well motivated teachers with high personal and professional discipline, integrity and competence (NCCE, 2012). This goal necessitated the Curriculum framework which was produced to guide the entire Nigeria Certificate in Education (NCE) awarding institutions nationwide, towards producing effective teachers through the establishment of teacher education programme in the various states. The issue of uniformity across all various Colleges of Education had been taken care of through the dissemination of the curriculum implementation framework and the Nigeria Certificate in Education minimum standards in the various Colleges of Education across the nation.

The curriculum implementation frame work guiding the NCE programme has implications for the 9-year Basic Education Curriculum (BEC). This is because the NCE graduates are prepared to teach any of the classes in the 9-year Basic Education Programme (Primary 1 to J.S.S.3). This signifies there is need for an implementation-synergy between the NCE Curriculum and the 9-year Basic Education curriculum in Nigeria. Junaid (2013) clearly stated that one of the objectives of the NCE programme is to serve the 9-year Basic Education Curriculum. As part of the mandate, the teachers are to teach effectively the subjects they are meant to teach without being oblivious of the need for higher education of the beneficiaries. The NCE Integrated-science teachers are meant to implement the 9-year 
Basic Science Curriculum (BSC).

Various studies on curriculum evaluation have been carried out by researchers in the past years to find out the lapses observed in those curricula (Ajayi \& Emoruwa, 2012; Akanbi, 2010; and Moyinoluwa, 2015). Every new curriculum is meant to improve on the previous one and to meet changing social dynamics in line with best practices. Ajayi \& Emoruwa (2012) reviewed NCE Integrated Science Curriculum, Akanbi (2010) carried out a review of NCE physics curriculum while Moyinoluwa (2015) evaluated the 9-year BEC in Nigeria. Awofala, Ola-Oluwa \& Fatade (2012) investigated the perception of primary and junior secondary Mathematics teachers on the new nine-year Basic Education Mathematics curriculum in Nigeria. This study is a little different from the others because it will evaluate the implementation synergy between the topics, laboratory exercises and nature of assessment found in the two curricula which are the NCE Integrated-science curriculum and the 9-year Basic science curriculum. The NCE Integrated-science teachers are taught the contents of the NCE Integrated-science Curriculum in order to teach the content of the 9-year Basic Science Curriculum. Since two curricula are involved and the both the in-service and pre-service teachers are taught with the NCE Integrated-science curriculum in order to implement the 9-year Basic science curriculum, it becomes necessary to evaluate the implementation-synergy (teaching-content cooperation) between the NCE Integrated-science and the 9-year Basic science curricula in Nigeria. In this study, implementation synergy refers to the relationship or cooperation that exists between the two curricula in terms of teaching the topics, carrying out laboratory exercises and assessing the students. Thus the perceptions of the in-service and pre-service teachers were sought.

For the pre-service teachers, teaching practice is one of the crucial aspects of the NCE programme. It gives them the opportunity to acquire personal professional skills through practice. These NCE pre-service teachers usually go for teaching practice exercise as a mandatory requirement before graduation, there is need to find out if they are fully prepared to teach the content of the 9-year Basic science curriculum, carry out laboratory exercises; and carry out assessment in all the basic science topics they are meant to teach.

The revised NCCE Curriculum framework and curriculum content has being in use since 2012 and is purposely to serve the present 9- year Basic Education Curriculum. The present NCE students and NCE graduates who graduated after 2012 are products of this revised NCE Curriculum and will be used in this study. This study will evaluate the implementation synergy between NCE integrated-science and 9-Year basic science curricula with reference to the topics, laboratory exercises and nature of assessment which are part of the NCCE implementation framework guiding the NCE Programme in Nigeria.

\subsection{Objectives of the Study}

In line with the guideline in the NCCE curriculum framework for all NCE degree awarding institution across Nigeria, there is a mandate to produce quality teachers for the Basic Education sub-section. This study seeks to evaluate the implementation-synergy between NCE Integrated science curriculum and the 9-year basic science curriculum in order to identify possible gaps in their content areas, laboratory exercises and nature of assessment. This study has behind it the following specific goals:

1. To find out if the topics in the 9-year Basic Science Curriculum (BSC) are different from those in the NCE Integrated-science curriculum (ISC).

2. To find out if the laboratory exercises in the 9-year BSC are different from those in the NCE Integrated-science curriculum

3. To find out if the nature of assessment in the 9-year BSC differs from that of the NCE Integrated-science curriculum.

4. To find out if the perceptions of the in-service and pre-service teachers differs about the synergy between the 9 -year BSC and the NCE Integrated-science curriculum.

The results of this study will have high impact on education in the following ways:

1. The results may be useful for the next curriculum revision exercises for both the 9-year basic science and NCE Integrated-science curricula (Implementation of the present NCE curriculum began in 2012 which makes it due for a review).

2. This study is expected to reveal underlying issues faced by the NCE integrated science in-service and pre-service teachers in their teaching of the basic science curriculum. These issues will be presented before the curriculum planners for further actions.

3. Based on the findings from the perceptions of the in-service and pre-service basic science teachers about 
synergy in both curricula with reference to topics, laboratory exercises and nature of assessments, workable suggestions will be given to the planners of the NCE Integrated- science and 9-year basic science curricula for improvement.

4. Finally the results of this study are expected to be raw materials for use to further build up the experience of NCE-Integrated-science Lecturers, Basic science teachers, curriculum planners and all teachers at large.

\section{Literature Review}

Curriculum is regarded as a means for enabling and managing educational change and development in the school system and teachers are regarded as key agents of change in the process of implementing the curriculum. This is because they prepare the lesson following the content given to them and impact the knowledge they have on their students (Atomatofa, Avbenagha \& Ewesor, 2013). For the pre-service teacher, it is expected that he has to do field work called teaching practice before he graduates to become a professional teacher. This means he is in a training period to also become a professional agent of change. The concept of this study centers on finding out if there is synergy between the NCE Integrated-science and 9-Year Basic science curricula.

The theoretical framework of the study draws from Kerr's curriculum model which has four areas (Objectives, Knowledge, Evaluation, and School learning experiences) that are interrelated directly or indirectly. The Objectives are derived from experiences and knowledge acquired as a result of school learning; knowledge derived from the topics or courses should be organised, integrated, sequenced, and reinforced; evaluation involves the collection of information for use in making decisions about the curriculum while school learning experiences are influenced by various relationships which includes pupil and teacher relationships, teaching methods, content and the maturity of the learners. These experiences are evaluated through interviews, assessments and other reasonable methods. Kerr explains in this model that everything influences everything else and that it is possible to start an evaluation at any point. Drawing from this model, both the pre-service and in-service teachers to be use for this study have passed through the NCE Integrated science curriculum and are teaching or have taught basic science in any of the classes in the 9-year basic education programme. There is a relationship between the 2 curricula in objective, content knowledge and assessment including learning experiences which includes carrying out laboratory practicals. Decisions made from this evaluation exercise will be useful in making decisions for future curriculum reviews.

Studies show that the most teachers have poor concept of teaching as mere transmission of knowledge and they lack the skill to link the content of the NCCE to that of the 9 year Basic Education Curriculum. Some reasons for these flaws according to Imogie (1990) are: Inadequate preparation of the teachers before qualifying as teachers and lack of a model - teaching practice laboratory in the Colleges of Education where such trainings are done and this inadequate training is having implications on the 9-year basic education programme because NCE graduate becomes Basic education teachers. It is important for teachers to see the interaction between the NCE and Basic Education curricula. Most teachers do not have access to the 9-year Basic science curriculum nor the topics or course syntheses containing the topics in the subject they would teach as teachers (Ojo, 2014). Some basic science teachers never did education courses or specifically, Integrated science courses in school but were wrongfully employed to teach basic science leaving out those who are qualified to be jobless (Meyanga, 2015). If the Basic science teachers pass through NCE Programmes and had proper access to the Basic science curriculum before graduation from the NCEprogramme, it will enable them report any topic they find out they cannot teach very well to their lecturers so that a remedial would be done on those areas before actual graduation. A lot of trainee teachers during their teaching practice exercise have no access to the curriculum.

Sambo, Kukwi, Eggari \& Mahmuda (2014) carried out an assessment of the implementation of basic science programme in junior secondary schools in Nasarawa and they found that lack of effective synergy and proper communication between the State Ministry of Education and Universal Education Board has affected effective distribution and the implementation of the Revised 9-Year BEC. In the present study the researchers seek to find out the synergy in the topics, laboratory exercises and nature of assessment in the NCE Integrates-science and 9-year basic science curricula. Personal interviews with some teachers' revealed lack knowledge of the laboratory exercises they are supposed to carry out while implementing the 9-year basic science curriculum. Some of them did not even know they were supposed to carryout practicals with the Basic science students. Personal interview also revealed that either the teachers did not do laboratory exercises during the NCE- programme or the laboratory exercises they were taught were a little different from those in the 9-year Basic science curriculum. The Integrated - Science NCE and 9-year basic science Curricula are designed such that laboratory exercises are required in some of the topics/courses.

On nature of assessment, teachers of basic science should be conversant with the kind of assessment expected in the 
9-year basic science curriculum before graduating from the NCE-Integrated-science programme. Tim- lawyer (2015) found out that NCE-lecturers lack in-service training and lack current information on assessments in the curriculum of the Basic Education programme and so they cannot pass basic information to their pre-service teachers on assessment in implementing the 9-year basic education curriculum. This ignorance has affected the trainee - teachers. If the lecturers are acquainted with all the guidelines in the curriculum of the 9 - year basic education programme, it will be easier for the pre-service teachers when they graduate and become teachers.

Awofala, Ola-Oluwa and Fatade (2012) carried out a study on Teachers Perception of the Basic Education Curriculum in Mathematics and it was discovered that the teachers irrespective of differences in their status unilaterally agreed that they had a high degree of ownership of the content of the new basic education mathematics curriculum despite their lack of necessary training in the principles underpinning the curriculum. In this study the perceptions of the pre-service and in-service teachers about the synergy of the NCE integrated-science and 9-year basic science curricula will be compared.

\section{Research Questions/Hypotheses}

\subsection{Research Questions}

1. Is there implementation synergy between "topics" found in the 9-year basic science and the NCE Integrated-science curricula?

2. Is there implementation synergy between "laboratory exercises" found in the 9-year basic science and the NCE Integrated-science curricula?

3. Is there implementation synergy of "nature of assessment" in the 9-year basic science and that of NCE Integrated-science curricula?

4. Do the perceptions of the in-service and pre-service teachers differ about the NCE Integrated-science and 9-year basic science curricula?

\subsection{Research Hypotheses}

1. There is no significant difference between teachers who agreed and disagreed that there is implementation synergy between topics found in the NCE integrated-science and 9-year basic science curricula.

2. There is no significant difference between teachers who agreed and disagreed that there is implementation synergy between "laboratory exercises" found in the NCE integrated-science and 9-year basic science curricula

3. There is no significant difference between teachers who agreed and disagreed that there is implementation synergy in "nature of assessment" between the NCE integrated-science and 9-year basic science curricula.

4. The perceptions of the in-service and pre-service teachers do not differ significantly about the synergy of the NCE Integrated-science and 9-year basic science curricula.

\section{Method}

\subsection{Research Designs}

This study employed the descriptive cross sectional survey design. Information from respondents was obtained at a single period in time.

\subsection{Participants}

The participants of the study consist of 180 Basic Science pre-service and in-service teachers from the six states in the South-South Geo-political zones in Nigeria. 120 were pre-service 300 level students who have completed their teaching practice exercise while 60 were in-service basic science teachers from primary and secondary schools in the state. All the respondents used were those who were recipient of the present 2012 NCCE new Curriculum and who teach Basic science presently or pre-service teachers who taught Basic science during their teaching practice exercise.

\subsection{Instrument (Validity and Reliability)}

A four point, 24-item questionnaire called the "Curriculum Implementation Synergy Questionnaire" (CISQ), was used to obtained data from the 180 respondents. The scaling factors contained in the CISQ were: Synergy of Topics (SOT), Synergy of Laboratory Exercises (SOLE), Synergy of Assessment (SOA) and Perception of Teachers (POT). The questionnaire consists of 4 options: strongly agreed; agreed; disagreed and strongly disagreed. 
The CISQ was developed by the researchers and used for data collections. The face validation was done by experts in the field of curriculum and science education to make for editing and avoidance of ambiguity. The CISQ reliability testing was done by carrying out a pilot study of 30 pre-service teachers who did not form part of the sample for the study and the Cronbach alpha reliability testing was used to test for internal consistency reliability.

Initially the questionnaire consist of 25 items but after the reliability testing, one item appeared not worthy of retention hence it was deleted making the items 24 and a Cronbach alpha reliability of 0.75 was obtained for all the items. This is an acceptable level according to George and Mallery (2003) rule of thumb for the Cronbach alpha. For the reliability of each of the 4 scaling factors, reliability co-efficient of $0.61,0.86,0.71$ and 0.60 were respectively obtained for items 1-7 (synergy of topics), 8-11 (SOLE), 12-17 (SOA), and 18-24 (POT). Table 1 is a sample of the CISQ used as instrument for the study

Table 1. Curriculum Implementation Synergy Questionnaire

\begin{tabular}{|c|c|}
\hline & Synergy of Topics \\
\hline 1 & $\begin{array}{l}\text { I do not have difficulties in teaching B/Sci. topics because I was taught the same topics in my } \\
\text { NCE int.science program. }\end{array}$ \\
\hline 2 & $\begin{array}{l}\text { Any teacher who passes through NCE Int./Science dept. will not have problem teaching Basic } \\
\text { Science topics. }\end{array}$ \\
\hline 3 & Topics not found in Basic Science but found in NCE Int./Sci. should be removed. \\
\hline 4 & $\begin{array}{l}\text { NCE Int. / Sci. pre-service should have access to the topics in 9-year basic science curriculum } \\
\text { before commencement of T.P exercise. }\end{array}$ \\
\hline 5 & NCE Int./Sci. pre-service teachers should be taught all basic science topics before T.P \\
\hline 6 & Some of the topics in the 9-year basic science are not found in the NCE curriculum. \\
\hline 7 & $\begin{array}{l}\text { NCE Int. / Sci. pre-service teachers should be made to complete all their course work in first } \\
\text { semester year } 3 \text { before commencing T.P in } 2^{\text {nd }} \text { semester year } 3 \text {. } \\
\text { Synergy of Laboratory Exercises }\end{array}$ \\
\hline 8 & $\begin{array}{l}\text { The science practicals we were taught in the NCE program are similar to those I taught in the } \\
\text { basic science classes. }\end{array}$ \\
\hline 9 & $\begin{array}{l}\text { I did not have difficulties in carrying out practical with my basic science students because I } \\
\text { understood the practical during my NCE program. }\end{array}$ \\
\hline 10 & $\begin{array}{l}\text { Laboratory exercise were carried out in their science laboratory the same way they were carried } \\
\text { out in my NCE integrated science Lab. }\end{array}$ \\
\hline 11 & $\begin{array}{l}\text { The field trips experiment I had as NCE Int./Sci. student are not different from those in the } \\
\text { 9-year basic science curriculum. } \\
\text { Synergy of Assessment }\end{array}$ \\
\hline 12 & The methods of assessment in NCE Int./Sci. are similar to those of 9-yr Basic Science \\
\hline 13 & C.A is $40 \%$ while exam is $60 \%$ in both NCE and Basic Science. \\
\hline 14 & $\begin{array}{l}\text { Basic science students were given continuous assessment the same the NCE Int. Sci. students are } \\
\text { given. }\end{array}$ \\
\hline 15 & Exam questions in both $\mathrm{B} / \mathrm{Sci}$. and NCE int.science are objectives and theory questions. \\
\hline 16 & $\begin{array}{l}\text { The exam questions in both } \mathrm{B} / \mathrm{Sci} \text {. and NCE Int./Sci. are drawn from the topics taught that } \\
\text { term/semester. }\end{array}$ \\
\hline 17 & $\begin{array}{l}\text { The duration of assessment is ok in both B/Sci. and NCE Int./Sci. } \\
\text { Perception of Teachers }\end{array}$ \\
\hline 18 & There is synergy of topics in the NCE Int./Sci. and 9-year B/Sci. curriculum. \\
\hline 19 & There is synergy in the laboratory exercises in both NCE Int./Sci. and Basic science. \\
\hline 20 & There is synergy in the nature of assessment in both NCE Int./Sci. and Basic science. \\
\hline 21 & Anyone who studied NCE Int./Sci. can teach Basic science. \\
\hline 22 & Anyone who did not study NCE Int./Sci. should not teach Basic science. \\
\hline 23 & There is need to evaluate the NCE Int./Sci. and 9-year Basic sci curricula to align \\
\hline 24 & Those who teach Int. Sci. in T.P should complete NCE before doing T.P. \\
\hline
\end{tabular}

\subsection{Procedure for Data Collection and Analysis}

Questionnaires were given to the students and collected same day by research assistants sent to all the schools and 
the 180 questionnaires were used for the data analysis. The responses were summed up and analyzed and descriptive statistics were used to answer the research questions while Z-test for single proportion was used for analysis of hypotheses 1-3 and the independent sample t-test was used for analysis of hypothesis 4 .

Those who agreed that there was synergy were grouped against those who disagreed. For the scale I consisting of 7 questions the highest score of 28( 4 for strongly agreed times 7 questions) can be obtained, a bench mark of 14 was used to group the respondents into 2 groups, 'synergy group' and 'no synergy group'. Thus those who had a summed up score of 15-28 were grouped as synergy while 0-14 as 'no synergy group'. Means, standard deviation and mean differences were compared.

\section{Results and Discussion}

\subsection{Research Question One}

Is there implementation synergy between topics found in NCE integrated-science and the 9-year Basic Science Curriculum.

Table 2. Descriptive Statistics for Responses for Synergy of Topics

\begin{tabular}{lllllll}
\hline SOT (items 1-7) & No. & EX & X & SD & S.E & M.D \\
\hline Synergy & $151(83.9 \%)$ & 3104 & 20.6 & 3.10 & 0.26 & \\
$\begin{array}{l}\text { No synergy } \\
\text { Total }\end{array}$ & $29(16.1 \%)$ & 359 & 12.4 & 1.29 & 0.24 & 8.20 \\
\hline
\end{tabular}

Table two shows responses from the 180 teachers. 151 teachers (X 20.6, SD 3.1, 83.1\%) agreed that there was synergy of topics while 29 teachers (X 12.4, SD 1.29, 16.1\%) said there was no synergy of topics between the 2 curricula. The mean difference between those for synergy and those for 'no synergy' is 8.2. A greater percentage $83.9 \%$ of the teachers agreed that there was synergy, but the analysis of Hypothesis one will tell if the difference in agreement is significant or not.

\subsection{Analysis of Hypothesis One}

There is no significant difference between teachers who agreed and disagreed that there is implementation synergy between topics found in the NCE integrated-science and 9-year basic science curricula.

Table 3. Z-Test for a Single Proportion for SOT

\begin{tabular}{llllllll}
\hline & No. & Synergy & No synergy & $\begin{array}{l}\text { Synergy } \\
\text { Proportion }\end{array}$ & $\begin{array}{l}\text { Z-test } \\
\text { cal }\end{array}$ & $\begin{array}{l}\text { Z-test } \\
\text { cri }\end{array}$ & Decision \\
\hline $\begin{array}{l}\text { Z-test } \\
\begin{array}{l}\text { Mann Whitney } \\
\text { U-test }\end{array}\end{array}$ & 180 & SOT & $\begin{array}{l}151 \\
\text { The Mann-Whitney U-test }\end{array}$ & $\begin{array}{l}0.84 \\
\text { was significant at }\end{array}$ & $\begin{array}{l}8.000, \\
\text {, thus Ho was rejected. }\end{array}$ \\
\hline
\end{tabular}

The Null Hypothesis one is rejected because a significant difference occurred between the responses of those that agreed there was synergy and those who say there is no synergy. The Z-test at 8.5 is greater that the $\mathrm{Z}$ table value of 1.96 at 0.05 , level of significance. This means there is a significant difference between those who agreed that there was synergy and thus who say there is no synergy of topics between the 2 curricula with those who say there is synergy having a greater percentage $83.9 \%$ or mean value of (20.6) against those who said there was "no synergy" (16.1\% and mean of 12.4$)$.

This finding is in agreement with that of Sambo, Kukwi, Eggari \& Mahmuda (2014) who carried out a study on assessment of the implementation of Basic Science program in Junior Secondary School in Nasarawa. They found out that a majority of the respondents strongly agreed and agreed that the program was being implemented as supposed. Also this study is in line with that carried out by Awofala, Ola-Oluwa and Fatade(2012) on teachers perception of the Basic Education Curriculum in Mathematics where it was discovered that the teachers unilaterally agreed that they had a high degree of ownership of the content of the new basic education mathematics curriculum despite their lack of necessary training in the principles underpinning the curriculum. This means the topics they were taught in their NCE or Higher institutions were similar to what they were teaching hence their high degree of ownership of the BEC content in Mathematics. However contrary to this finding was the finding in a study carried out by Sambo, Kukwi, Eggari \& Mahmuda (2014) where they found that there was no effective synergy and proper 
communication between the State Ministry of Education and Universal Education Board and that affected effective distribution and the implementation of the Revised 9-Year BEC. This present study, carried out four years after Sambo, Kukwi, Eggari \& Mahmuda (2014)'s study, had indications of effective synergy and proper communication between the state and UBE and the teachers implementing the curriculum. The teachers were well informed of the topics in the 9-year basic science curriculum mostly because of the synergy the topics had with the NCE Integrated science curriculum with which they themselves were taught while they were students in NCE Integrated-science.

A side by side face evaluation of the two curricula also carried out by the researchers' shows that a thorough work was done by the curriculum planners in ensuring that the topics in the revised 9-year Basic Science curriculum were similar to the NCCE integrated science topics. Only few topics omitted in the NCCE integrated science curriculum were found in the Basic Science Curriculum. These are: forms of technology; developed and under-developed technology. Drug abuse for instance is found in the Basic science curriculum but is an elective course ISC 325 in the NCE integrated-science curriculum. Another topic: soil and types, found in the Basic science curriculum was found only in an elective course ISC 324 (the earth and the moon) in the NCE Integrated-science curriculum. It is sad that most of the NCE students avoided doing elective courses so they do not have the opportunity to study these topics found in the Basic Science curriculum. However only few topics were not in synergy in both curricula; it means there is a great degree of implementation synergy in the both curricula. Hypothesis one was rejected because there was a significant difference between those who agreed and disagreed about the synergy of topics in both curricula in favored of the agreed.

\subsection{Research Question Two}

Is there implementation synergy between laboratory exercises found in the 9-year basic science and NCE integratedscience curricula?

Table 4. Showing Descriptive Statistics for Responses of Teachers on Synergy of Lab Exercises (SOLE)

\begin{tabular}{lllllll}
\hline SOLE (Items 8-11) & No. & EX & X & SD & S.E & M.diff \\
\hline Synergy & $142(78.9 \%)$ & 1728 & 12.17 & 1.92 & 0.16 & \\
$\begin{array}{l}\text { No synergy } \\
\text { Total }\end{array}$ & $38(21.1 \%)$ & 284 & 7.47 & 0.95 & 0.15 & 4.7 \\
\hline
\end{tabular}

The result in the table 4 shows that 142 of the teachers which represents $78.9 \%$ of the total population with a mean value of 12.17 agreed that there was synergy of laboratory while only 38 of the teachers with a mean value of 7.47 and a percentage of value $21 \%$ did not agree that there was synergy of the laboratory exercises in the two curricula. The mean difference was 4.7 which means a difference occurred but analysis of Hypothesis two will tell if the difference is significant or not.

\subsection{Hypothesis Two}

There is no significant difference between teachers who agreed and disagreed that there is implementation synergy between laboratory exercises found in the NCE integrated-science and 9-year basic science curricula

Table 5. Summary Table for Z-Test for a Single Proportion for SOLE

\begin{tabular}{|c|c|c|c|c|c|c|c|}
\hline test & No & synergy & No synergy & $\begin{array}{l}\text { Proportion } \\
\text { synergy }\end{array}$ & Z-cal & Z-table & Decision \\
\hline Z-test & 180 & 142 & 38 & 0.79 & 7.20 & 1.96 & S.D \\
\hline Mann Whitney U-test & 180 & Significa & difference fou & $\mathrm{d}$ at 0.0000 at & $<0.05 \mathrm{tl}$ & refore rej & cted $\mathrm{HO}_{2}$ \\
\hline
\end{tabular}

The null hypothesis of no significant difference between the proportion of teachers who agreed and disagreed that there is synergy of laboratory exercises in the two curricula is rejected because a Z-test value of 7.20 was found and it is greater than the table value of 1.96. The Mann Whitney U-test also gave a significant value of 0.000 which is lesser than the $\mathrm{P}$ value at 0.05 . Thus $\mathrm{HO}_{2}$ was rejected, meaning there was a significant different in teachers who agreed and disagreed that there was synergy of lab exercise found in the two curricula.

Laboratory exercises are designed to be part of the topics in the curricula for the NCE integrated science and 9-year basic science. Agbidye (2015) explained that Basic science teachers are aware of, were taught and could carry out most of the laboratory exercises but due to lack of infrastructure in Nigerian schools, the basic science hardly carry out these laboratory exercises except when necessary during laboratory practicals in examination time. In this study 
it was found out that a majority of the teacher (78.9\%) agreed that there was synergy in the exercises in both curricula. Since a greater percentage agreed that there was synergy it means like Agbidye (2015) explained, the teachers had knowledge of the practical sessions found in both curricula although some excused lack of infrastructures for carrying out practical regularly. A side by side face evaluation of the laboratory exercises found in both curricula showed that the laboratory exercises in both curricula were similar except in "collecting and identifying of farm or garden tools" which was found in the 9-year basic science curriculum but was not found in the NCE integrated-science curriculum.

\subsection{Research Question Three}

Is there implementation synergy in 'nature of assessment' between the 9-year basic science and NCE Integrated science curricula?

Table 6. Showing Descriptive Statistics on Responses for Teachers on Synergy of Assessment

\begin{tabular}{lllllll}
\hline SOA items 12-17 & N & EX & X & SD & S.E & M. diff \\
\hline Agreed & $140(77.8 \%)$ & 2338 & 16.7 & 3.20 & 0.27 & \\
Disagreed & $40(22.2 \%)$ & 484 & 12.1 & 3.59 & 0.56 & 4.6 \\
Total & $180(100 \%)$ & & & & & \\
\hline
\end{tabular}

The table 5 shows that 140 teachers $(77.8 \%$ (X 16.7) agreed that there was synergy of assessment in both the NCE Int./science and 9-year BEC while 40 teachers $(22.2 \%, \mathrm{X}=12.1)$ out of the 180 teachers disagreed that there was synergy in assessment. The mean difference of 4.6 was seen and there result of analysis of HO3 using z-test of a single proportion as well as the Mann-U Whitney test is seen in the table 7.

\subsection{Hypothesis Three}

There is no significant difference between responses of teachers who agreed and disagreed that there was implementation synergy in nature of assessment in NCE Integrated-science and 9-Year basic science curricula.

Table 7. Summary Table for Z-Test for a Single Proportion for SOA

\begin{tabular}{lllllll}
\hline No of responses & Synergy & No synergy & Synergy Proportion & Z-cal & Z-table & Decision \\
\hline Z-test & 140 & 40 & 0.77 & 6.75 & 1.96 & S.D \\
Mann Whitney U-test & \multicolumn{2}{l}{ Significant difference found $\mathrm{P}<0.05$ therefore rejected Null hypothesis } \\
\hline
\end{tabular}

The Z-test of a single proportion result as seen in table $7(6.75>1.96)$ shows a significant difference was found in the proportion of teachers who said there was synergy and those who said no synergy. Thus the Null hypothesis 3 of no significant implementation synergy between nature of assessment in the NCE ISnt./science and 9-year basic science curricular was rejected because a significant difference was found in favour of those that agreed that there was synergy.

Personal interview with some of the teachers showed that more than $50 \%$ of teachers interviewed believed there was synergy of assessment while the others say there is synergy in some areas but not in all areas. Some of them suggested that the assessment in the 9-year BEC should be based on only topics the students have been taught and not in all areas of the curricula not minding if they have been taught or not. Assessment is a very crucial aspect of teaching and learning as it can be a vital tool to facilitate effective learning and as Tim- lawyer (2015) found out, NCE-lecturers need more information on assessments in the curriculum of the Basic Education programme so that they can pass basic information to their pre-service teachers on assessment in implementing the 9-year basic education curriculum. This will be necessary since the teachers believe there is synergy in assessment in both curricula.

\subsection{Answer to Research Question Four}

\section{Research question 4:}

Do the perceptions of the in-service and pre-service teachers differ about the NCE Integrated-science and 9-year basic science curricula? 
Table 8. Showing the Proportion of Pre-Service and In-Service Teachers on the Synergy of Both Curricula

\begin{tabular}{llllllll}
\hline Variable set & $\mathbf{N}$ & $\mathbf{X}$ & SD & Synergy & $\begin{array}{l}\text { Synergy } \\
\text { proportion }\end{array}$ & "no synergy" & $\begin{array}{l}\text { "no } \\
\text { synergy" } \\
\text { Propn }\end{array}$ \\
\hline Pre-service & $\mathbf{1 2 0}$ & 19.3 & 4.04 & $107(59.4 \%)$ & 0.89 & $13(7.3 \%)$ & 0.11 \\
In-service & $\mathbf{6 0}$ & 18.6 & 3.45 & $54(30 \%)$ & 0.90 & $6(3.3 \%)$ & 0.10 \\
Total & 180 & & & $161(89.4 \%$ & 0.89 & $19(10.6 \%)$ & 0.11 \\
\hline
\end{tabular}

In table 8 , it is seen that the 120 pre-service teachers had a mean of 19.3 and a SD of 4.04 while the 60 in-service teachers had a mean of 18.6 and a SD of 3.45. The mean difference is low at 0.7 . A total of $89.4 \%$ of the teachers across the 2 groups agreed that there was synergy in both curricula. Of this $89.4 \%, 59.4 \%$ were pre-service teachers while $30 \%$ consists of in-service teachers. Also $10.6 \%$ of all the teachers disagreed that there was synergy in both curricula. Of this, $7.3 \%$ consist of the pre-service teachers while $3.3 \%$ were in-service teachers. Summarily a larger percentage of both groups agreed that there was synergy in both curricula. Both the pre-service teachers and the in-service teachers had similar perceptions about the synergy level of the two curricula.

\subsection{Analysis of Hypothesis 4}

The perceptions of the in-service and pre-service teachers do not differ significantly about the synergy of the NCE Integrated-science and 9-year basic science curricula.

Table 9. T-Test Analysis of Perception of Teachers on Synergy of Two Curricula

\begin{tabular}{lrccccccl}
\hline Variable set & \multicolumn{1}{c}{$\mathrm{N}$} & $\mathrm{X}$ & $\mathrm{s} . \mathrm{d}$ & $\mathrm{df}$ & $\mathrm{t}$-cal & $\mathrm{t}$-table & Sig 2tail & Decision \\
\hline Pre-service & 120 & 19.3 & 4.04 & & & & & NSD \\
In-service & 60 & 18.6 & 3.45 & 178 & 1.23 & 1.96 & 0.22 & \\
$\begin{array}{l}\text { Total } \\
\text { MannWhitney U-test }\end{array}$ & 180 & & & & & & & \\
of independent samples & & & 0.17 & Accept Ho \\
\hline
\end{tabular}

The calculated t-value of 1.23 in table 9 is lower than the table value of 1.96 and the $P$ value of 0.22 is greater than the 0.05 level of significant for a 2 tailed test. The Mann Whitney $U$ test for independent samples was also used and the Null hypothesis was accepted because the 0.17 is not significant since it is greater than the 0.05 level of significant for a 2-tailed test. All results shows that the distribution of all the variable as perceived by the two set of teachers were similar or the same hence the null hypothesis which says the perception of the in-service and pre-service teachers do not differ significant about the implementation the NCE int. science and the 9-year basic science curricula was accepted. The calculated t-value of 1.23 is lower than the table value of 1.96 and the P value of 0.22 is greater than the 0.05 level of significant for a 2 tailed test. The Mann Whitney $U$ test for independent samples was also used and the Null hypothesis.

A similar research carried out by Awofala, Ola-Oluwa and Fatade (2012) on teachers perception of the Basic Education Curriculum in Mathematics showed that the teachers irrespective of their status all had positive perception about the new curriculum, however contrary to this finding was results of a study was that carried by Ojo (2014) on perception of teachers about the new Basic Education curriculum which showed that the teachers irrespective of their location generally had low perceptions about the new curriculum. The result of Ojo (2014) can be explained for because it was carried out about four years ago when the awareness was quite low but now, the teachers have ready access to the new curriculum hence the teachers in this study which was across six states showed similar positive perceptions about the curriculum synergy of both the NCE Integrated-science and 9-Year basic science curricula. The areas where they complained of no synergy were few and it was generally agreed that there were no synergy in such areas.

\section{Conclusion}

This study was carried out to find out if there was synergy of topics, laboratory exercises and nature of assessment in both the NCE integrated science curriculum and the 9-year basic science curriculum. The study also found out if the perceptions of the pre-service teachers and the in-service teachers who teach basic science in the 9-year BE program were similar about curriculum synergy.

Hypotheses one, two and three were rejected because results showed that there were significant differences in 
proportion of teachers who agreed and disagreed that there was synergy of topics, laboratory exercises and nature of assessment in both curricula in favor of the agreed. Thus we could generally say this study shows that there is synergy of topics, laboratory exercises and nature of assessment between the two curricula. However one area that needs attention that the interviewed teachers pointed out was on the nature of assessment in the NCE integrated science course and that of grade 6 and 9 basic-science final assessment. Those of the grade 6 and 9 basic science were standardized final certificate examinations across the nation. They suggested that the NCE-Integrated science program final certificate should also end with such standardized examination across the country since the curriculum is the same.

Hypothesis four was accepted because no significant difference was found in perceptions of pre-service and in-service teachers about the implementation synergy in the two curricula. The perceptions of both the pre-service and in-service teachers about synergy were similar, possibly because all the respondents were recipient of the pre-service 2012 NCCE int. science curriculum. In-service teachers who graduated before this new curriculum were not used. Those who teach basic science in the 9-year BEC program should be graduates of NCE integrated science

In conclusion, a little review of the NCCE curriculum should be made in order to add the few topics in the Basic science curriculum which were not properly captured in the NCCE Curriculum; like drug abuse, farm tools and soil types.

A teacher who was not properly taught cannot properly teach. And a teacher who is taught topics other than what he will have to teach will have problem teaching as a result of lack of synergy between what he was taught and what he is expected to teach. Hence there is need for synergy of topics, laboratory exercise and nature of assessment between the teacher preparatory curriculum (NCCE curriculum) and the 9-year BE curriculum.

\section{Recommendations}

1) The present in-service teachers who were not trained with the present 2012 New NCCE curriculum should be given opportunity for retraining in short courses or seminars. These were not part of this research work.

2) It is recommended that just as the nature of assessment for basic science in the 9-year BEC is standardize for basic 6 and 9 certificate classes, it should also be standardized for the final second semester graduation examination for NCE Integrated -science students across the nation.

3) Those topics and laboratory exercises not found in the NCCE integrated science curriculum but found in the 9-year BEC should be added not as electives but core courses

\section{Acknowledgment}

We specially acknowledge TETFund Nigeria for the sponsorship of this project as part of 2015/16 institutional based research funding given to lecturers in higher institutions to conduct researches across the country.

\section{References}

Agbidye A. (2015). Challenges and Prospects in the teaching of Basic Science at the upper basic level in Nigeria. Journal of Qualitative Education, 11(1), 1-8.

Ajayi, O., \& Emoruwa, E. (2012). Assessment of National Commission for Colleges of Education Curriculum in College of Education, Ikere-Ekiti. International Journal of Humanities and Social Science, 2(17), 299-302.

Akanbi, A. (2010). Education Education Physics curriculum Physics curriculum. Unpublished PHD thesis. University of Ilorin, Kwara State.

Atomatofa R., Avbenagha A., \& Ewesor S. (2014). A Survey of Science Teachers Awareness of Basic Education Curriculum in Nigeria. International Journal of Social Sciences and Education, 4(2), 339-345.

Atomatofa R., Omayuli M., \& Omayuli, V. (2014). An assessment of preparedness level and problems of students during teaching practice exercise. A case of Delta State College of Physical Education, Mosogar, Nigeria. International Journal of Advanced Research in Education, 2(2), 1-10.

Awofala A., Ola-Oluwa S., \& Fatade A. (2012). Teachers' Perception of the new 9-Year Basic Education Mathematics Curriculum in Nigeria. International Journal of Mathematics Trends and Technology, 3(1), 1-6.

FRN (NCCE 2012). Curriculum implementation framework for N.C.E. 2012 Edition 
George, D., \& Mallery P (2003). SPSS for windows. A simple guide and reference 11.0 update (4th ed.). Boston: Allym \& Bacon.

Imogie I. (1990). Student practice teaching and the Profession \& training of teachers in Nigeria: the need for a need strategy or the $21^{\text {st }}$ Century. Seminar, Faculty of Education $20^{\text {th }}$ Anniversary of the University of Benin - Benin City

Junaid, M. L. (2013). Introductory Section, National Commission for Colleges of Education Abuja. Curriculum Implementation framework for NCE. 2012 Edition

Meyanga, A. (2015). Why we revised curriculum-NCCE. News Agency of Nigeria.

Moyinoluwa, T. (2015). Implementation of the Revised 9-Year Basic Education Curriculum (BEC) in the Northcentral Nigeria: A Monitor of Benue State. IOSR Journal of Research \& Methods in Education, 5(3), 67-72. https://doi.org/10.9790/7388-05316772

Ojo A. (2014). Teachers' perception on New restructured 9-year basic education curriculum in Ekiti State Nigeria. IOSR Journal of Research \& methods in Education, 4(6), 21-26.

Sambo M., Kukwi I., Eggari S., \& Mahmuda A. (2014). Assessment of the Implementation of Basic Science Programme in Junior Secondary School in Nasarawa. Developing Country Studies, 4(20). 